\title{
Improving Learning Outcomes in Office Automation Subjects Through Development of Video-Based Media Learning Operating Microsoft Publisher 2010
}

\author{
Irma Mastumasari \\ Wasiti \\ Program Studi Pendidikan Administrasi Perkantoran Universitas Negeri Malang \\ Sulistyaningsih \\ SMK Negeri 1 Malang \\ Email: sarbini.fe.@um.ac.id
}

\begin{abstract}
The purpose of this research is to produce instructional media video-based operate Microsoft Publisher 2010 which is validated by experts for student at class X of Office Administration in SMKN 1 Malang through experimental class and control class. This study uses Research and Development research design ( $R \& D$ ) through 8 steps, namely: (1) research and information gathering early, (2) planning, (3) product development, (4) validation expert, (5) product revision, (6) the trial court (small groups), (7) the revision of the product, and (8) field trials (large group). Results of validation by material experts, media experts and 12 students, the media is expressed very valid and can be used. Based on $t$ test, it is known that a significant difference between the average student learning outcomes experimental class and control class, so that learning media can be said to be effective for use in the learning process.
\end{abstract}

Keywords: Instructional Media, Video, Learning Outcomes, Microsoft Publisher 2010

The development of information and communication technology has contribute to the revolution in various fields, education is one of them. The use of ICT as a base in today's learning becomes very important as it enables the acceleration of science transformation to student (Ospennikova, et al, 2015; Azlim, et al 2015; Aagaard, 2015). Utilization of ICT in learning activities can be done by providing innovative learning media to enhance the learning experience in more tangible direction (Rante, 2013; Panje, et al, 2016). Learning media is an intermediary that teachers use to channel messages/ information to students in the learning process in the form of text, audio, visual, video engineering and people to improve the understanding of learning materials or improve the quality of learning (Smaldino, et al 2011; Heinich in Mushiqon, 2012; Sadiman, 2012; Musfiqon, 2012). Learning media that can be used by teachers can be media presenter, media objects and interactive media (Haney and Ullmer in Miarso, 2004).

The use of instructional media clarify the presentation of the material so as not only to be verbalistic in the form of written or oral words conveyed by the teacher (Sadiman, 2012). So that teachers can improve students's understanding of 
learning in school (Azlim, et al, 2015; Surgenor et al, 2017; Fajriah and Churiyah, 2016; Panje, et al 2016). In reality today the use of media is still rarely applied in school. Teachers more often give the material directly and dominate the learning activities while the current demands are should be student oriented. The teacher should be able to utilize various tools to convey the message of teaching to students, in effort to utilize the media as a tool (Rante, et al, 2013), Edgar Dale held the classification of experience by level from the most concrete to the most abstract. Classification is then known by the cone of experience of Edgar Dale, as in the following picture

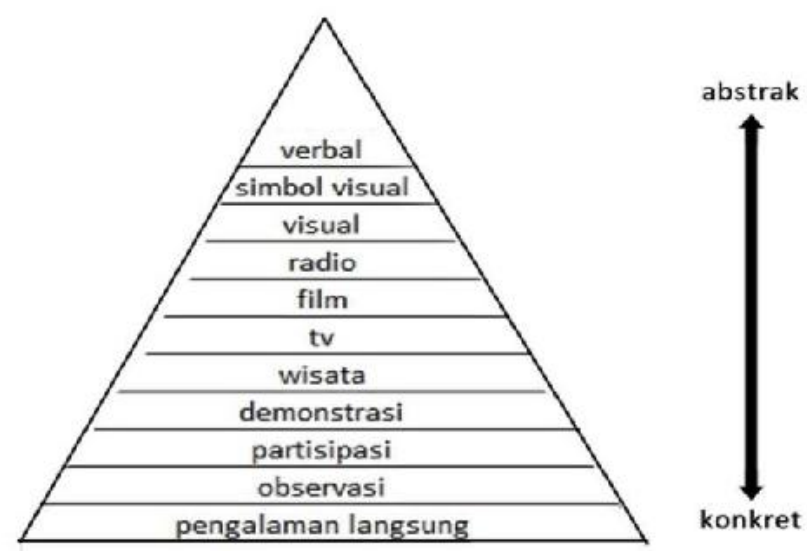

Figure 1. Edgar Dale's Cone of Experience Source: Sadiman, 2012:8

Based on the classification can be concluded that students who learen through verbal only have abstract knowledge. The cone of experience presented by Edgar Dale gives an idea about level of learning experience that students get based on media or tools used during learning process. The Edgar Dale's cone of experience currently widely adopted to determine the appropriated tools for a particular learning experience. The determination of instructional media should pay attention to : (1) learning objectives; (2) characteristics of learners; 93) become a learning resource; (4) efficiency and effectiveness; (5) safety for learnes; (6) developing learners creativity and creativity;97) develop a pleasant learning atmosphere; (8) media quality ( Setyosari and Akbar 2013).

SMK Negeri 1 Malang is a vocational secondary school referral in Malang City. This school has 7 majors which is Administration Office, Accounting, Marketing, Business Travel, Computer and Network Engineering, Audio-Video Engineering and Agribusinees. In learning process, this school has not been optimally utilizing the media, especially on Office Administration.

Teachers more often dominate in the process of teaching and learning, teachers demonstrate knowledge and skills, guide training, check understanding and provide opportunities for advance training. This learning model makes student depend on teacher's knowledge only during learning process. Adequate computer facilities for student and internet connections in computer labs have not been fully utilized. Computer facilities can support development of learning 
media to improve student learning outcomes (Azlim et al, 2015; Fajriah \&Churiyah, 2016; Sarihan et al, 2016).

Office Automation's leraning materials is more dominant with activities in the form of operation process, where sequential movement is important can be displayed more effectively. Video-based learning media can be used as an alternative teacher in delivering mearning materials (Surgenor, et al 2015; Fajriah \&Churiyah, 2016; Sarihan et al, 2016; Panje, Sihkabuden, Toenlioe 2016).

Messages presented in the video can be factual or fiction, can be informative, educative and instructional (Sadiman, 2012). The purpose of the instructional media is basically to improve student learning outcomes (Surgenor, et al 2015; Fajriah \&Churiyah, 2016; Sarihan et al, 2016; Panje, Sihkabuden, Toenlioe 2016). Learning outcomes are the abilities or change that students have after the teaching and learning activities, the ability possessed not only in the form of knowledge but also attitudes, behaviors, skills and ideals comprehensively to achieve the learning objectives (Dimyati \& Mudjiono, 2010; Suprijono, 2010; Kingsley 2011; Sudjana, 2011).

Based on background above, researchers tried to develop video-based learning media for Office Automation subject. So hopefully with this video-based learning media can overcome one of problems that exist in education so can motivate students learn actively and independently. The researchers is interested to study more and choose the title "Development of Video Based Media Learning to Improve Learning Outcomes in Office Automation Subjects Through Development of Video-Based Media Learning Operating Microsoft Publisher 2010 (Study On X Grade Student of Administration Office at SMKN 1 Malang)

METHOD

This research was conducted using a research and development model proposed by Borg and Gall 9in Setyosari, 2013) which was modified by researchers into 8 phase that could see in figure 2 below :

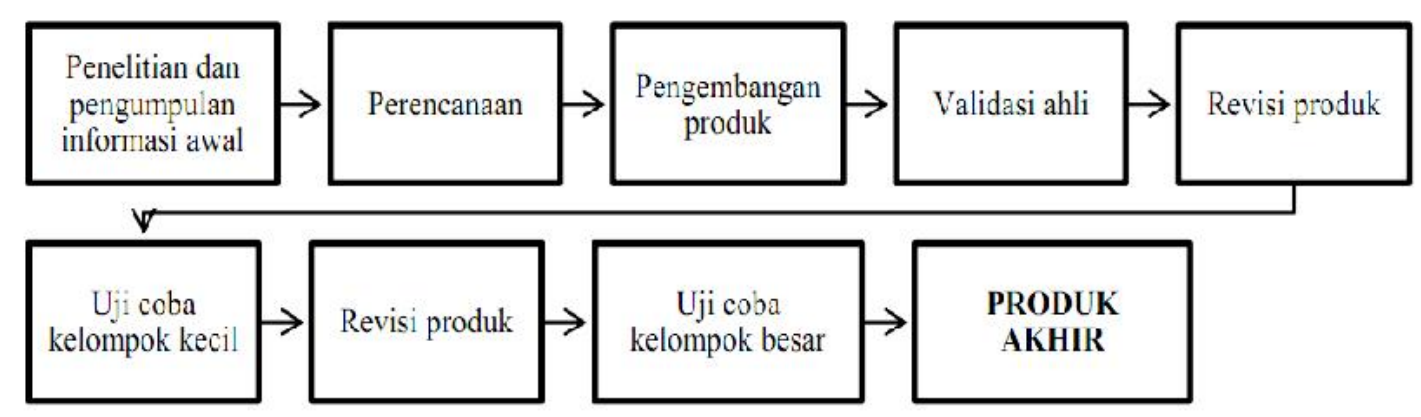

Figure 2. Procedur of video-based learning media Research and Development

Sumber: Borg \& Gall dalam Setyosari, 2013: 237-239, researcher's modified 
The result of development in this study were validated by material experts namely Ibu Sulistiyaningsih, M.Pd and media expert, Mr. Drs. H. Mohammad Arief, M.Sc. Small group trials were conducted on 12 of high, medium and low student ranking from X grade APK 2. The media feasibility assessment ws based on several indicators referring to the quality of content and objectives, instructional quality and technical quality. Large group trials were conducted on the X grade of Office Administration at SMK Negeri 1 Malang consisting of 2 classes: experimental class and control class. The determination of class based on student's daily test score on the Office Automation department. The researchers determines the class X APK 1 as the control class.

Types of data in this study are qualitative data and quantitavie data, quantitative data obtained from student learning outcomes. Qualitative data from media validation results from expert and small group trials are converted into quantitative data using likert scale. Quantitative data of media validation result were analyzed using descriptive analysis technique. Meanwhile, to anaylize the difference of learning result of experiment class and control class student Independent Sample T-test.

\section{RESULT \& DISCUSSION}

\section{Result}

This research and development deliver video-based learning media on Automation Office of Microsoft Publisher subject. Learning media develop using Camtasia Studio 8.0 application and supported by other applications such as Adobe Audition 1.5, Adobe Photoshop CS5 and Microsoft Powerpoint 2010. Camtasia Studio 8.0 used to record the Microsoft Publisher 2010 material and editing of video merging with audio. Adobe Audition 1.5 is used for audio recording narrative explanantion of the material, Adobe Photoshop CS5 is used to create a button logo of learning media and Microsoft Powerpoin 2010 is used to design the display of learning media. This learning media is packaged in compact disc (CD) with format.ppsx which can be opened using Microsoft Powerpoint application. The display of learning media consists of 7 main views. The first view is the initial instructional media menu, the second view is a material sitemap, the third view is the help, the fourth is the core competence, fifth is the basic competence, the sixth is learning objective and seventh view is the learning material menu consisting of learning activities 1 to 8 .

Based on data analysis of validation results to assess the feasibility of learning media conducted by material experts and media experts and students on small group trials, obtained data as follows. The feasibility assessment of instructional media is done based on the quality of content, instructional quality and technical quality (Arsyad, 2013: 219-220) assessed by material experts with a percentage average of $100 \%, 85 \%$ media experts and $90 \%$ students so it can be concluded that Video-based learning operates Microsoft Publisher developed by researchers declared to be very valid and can be used without revision in course learning Automation Office. 


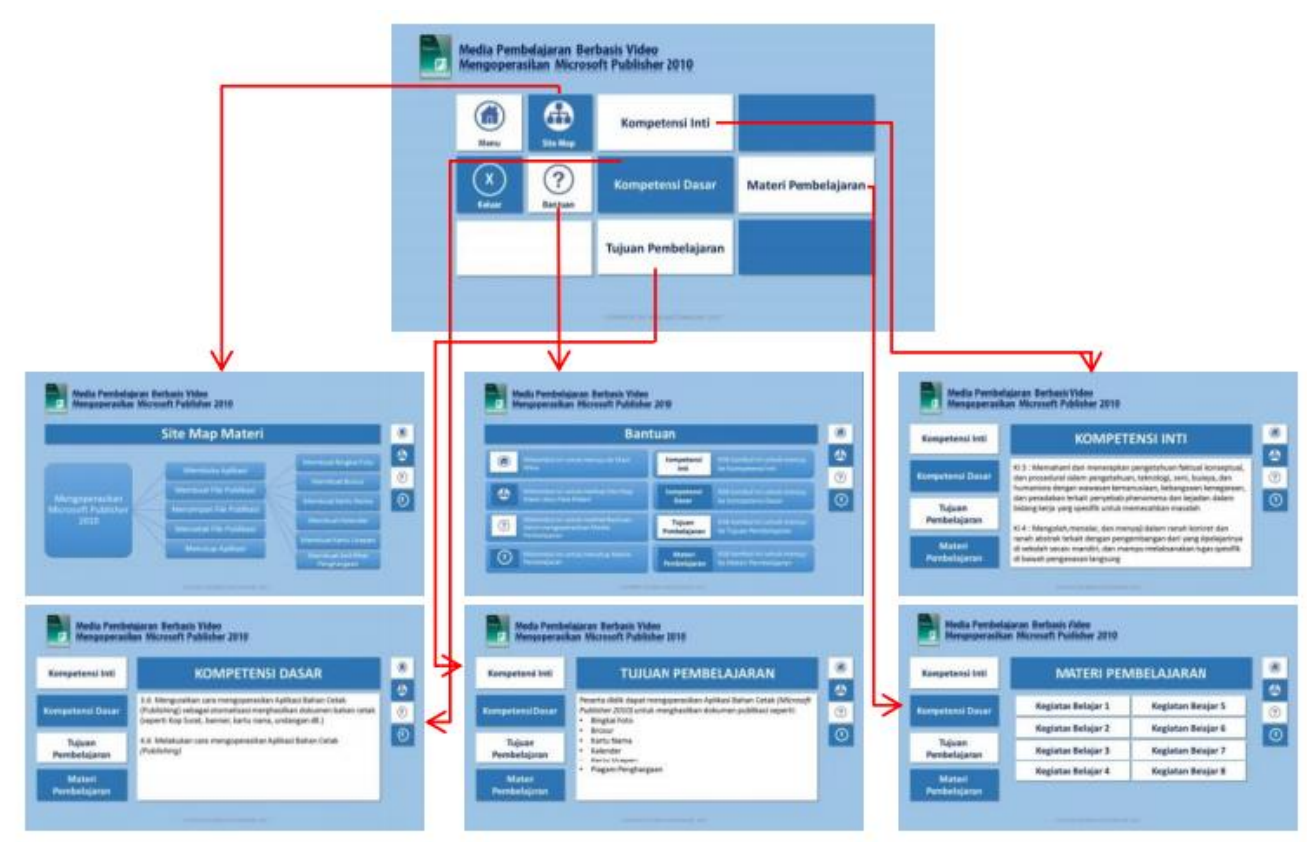

Figure 3. Learning Media View

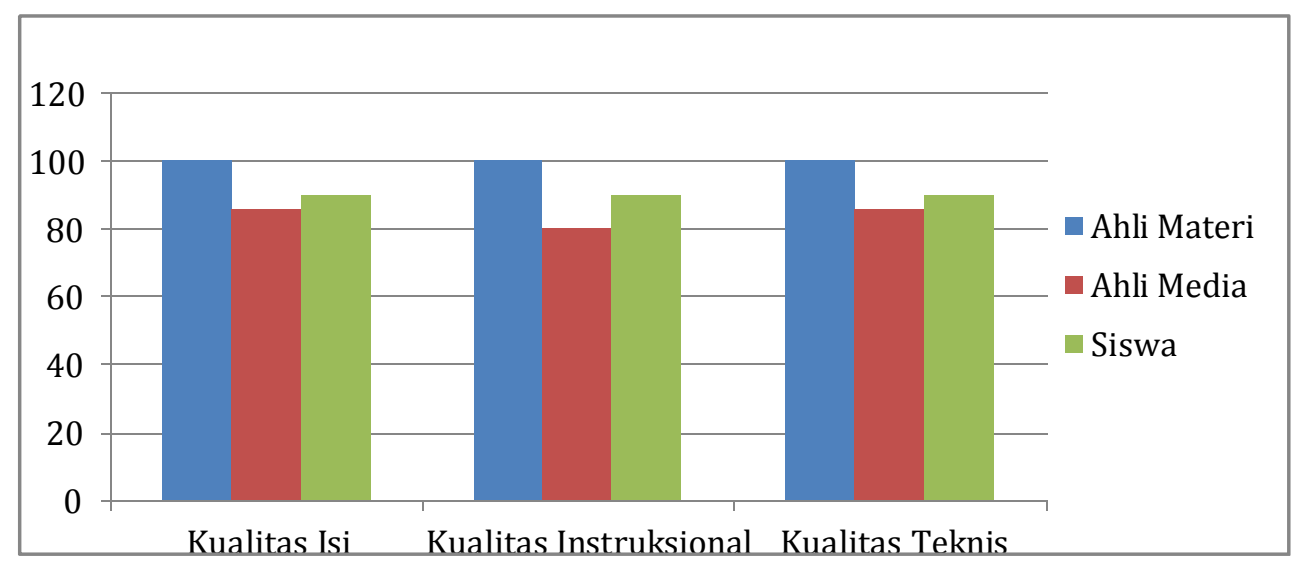

Figure 4. Learning Media Validation

Large group experiments in experimental group and control group, the researcher analyze the learning result data obtained by difference test of learning result $(\mathrm{t}$ test) to know the significance of difference learning result of experiment class and control class. Differences in student learning outcomes and different test a nalyzes can be seen in Table 1 below 
Table1. Result of Differences in Learning Outcomes

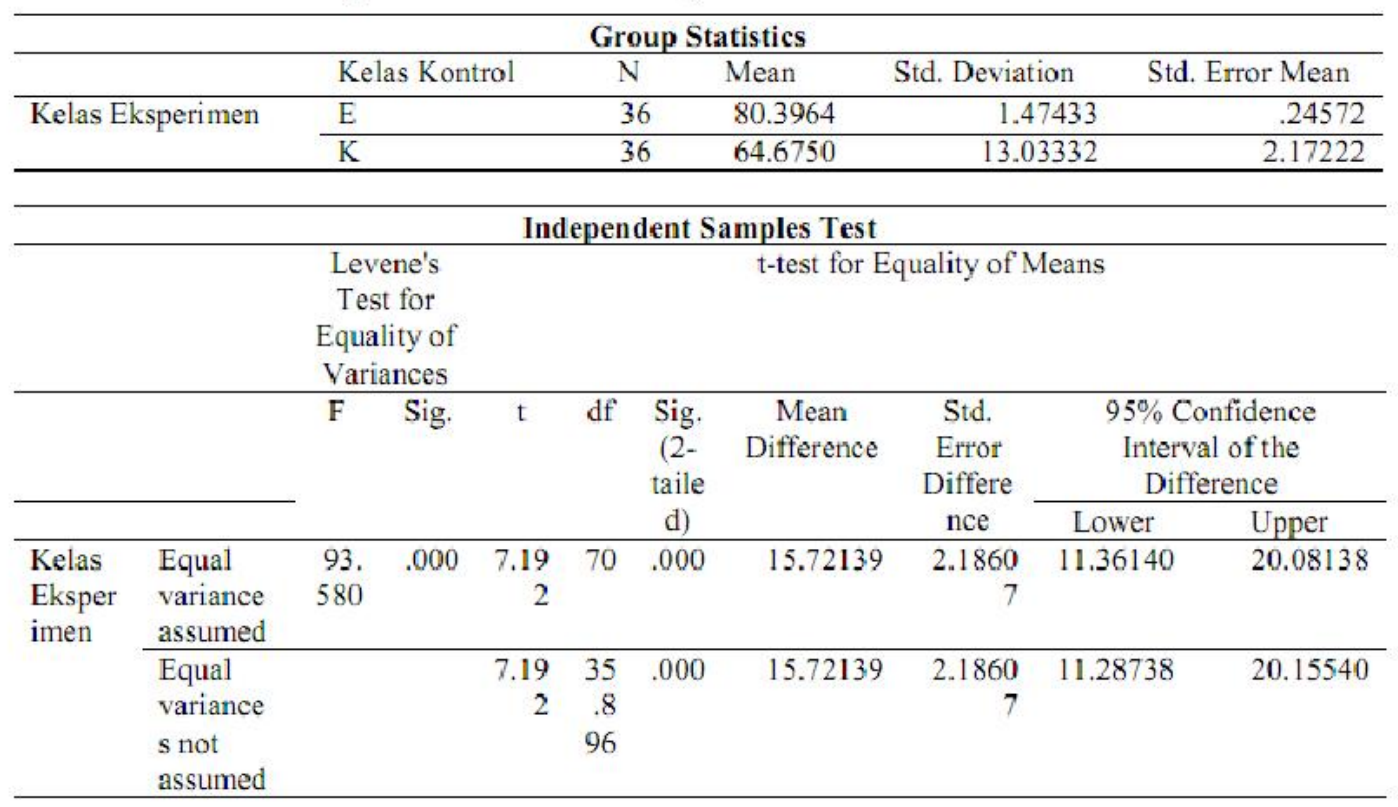

Table 1 shows the average of the experimental students' learning outcomes of 80.39, while the mean of the control class learning outcomes is 64.67. This indicates that the average of the students 'experimental class learning outcomes is higher than the average of the control class students' learning outcomes. In analyzing the results of this independent sample test two analyzes were performed, namely the analysis of Fcount for variance equality test and tcount analysis for the mean difference test. The Fcount analysis shows 93,580 with a significance of 0.000 ; Because the significance of $\mathrm{F}$ count $<0.05$; Then the two classes are not homogeneous (different), so for the t-test used column equal variances not assumed because it has unequal variations. It is seen that the test value of t-count is 7,192 with significance equal to 0,000; Because $0.000<0.05$; Then there is an average difference between the experimental group and the control group.

\section{Discussion}

Learning media is an intermediary that teachers use to channel messages / information to students in the learning process in the form of text, audio, visual, video, engineering and people to improve understanding of learning materials or improve the quality of learning (Smaldino, et al, 2011; Heinich (In Mushiqon, 2012); Sadiman, 2012; Musfiqon, 2012). In this case to help students understand learning materials to be more effective researchers try to present the relevant learning media to support learning activities in the classroom. Developed learning media combined with Microsoft Powerpoint 2010 applications to facilitate students use in the selection of learning media display that can combine images, text, audio, video and narration. In the learning materials that exist in the form of a video explaining is Microsoft Publisher 2010 applications so that students can understand every process of operation of Microsoft Publisher 2010 applications to 
produce publication files. Students can learn the material through the video repeatedly, this is according to the theory Smaldino (2011: 411) about the advantages of using video in the learning media that can display each process of successive operation clearly and students can see a performance repeatedly to be able to match in Learning skills.

Based on the results of expert validation, video-based learning media operating Microsoft Publisher 2010 has been fit in with learning objectives. According with the opinion of Setyosari and Akbar (in Akbar, 2013: 117-118) on the principle of choosing instructional media, conformity with the purpose of learning because the purpose of learning is the main consideration. Learning media has advantages, among others: (1) Video-based learning media operates Microsoft Publisher 2010 has an interesting display that can attract students to learn (2) Media-based video learning to operate Microsoft Publisher 2010 can help students to understand more learning materials to improve learning outcomes; (3) Video-based learning media running Microsoft Publisher 2010 can be easily duplicated by teachers and students so it can be used to study outside school hours independently.

The results of the study were supported by research conducted by Rante, et al (2013) and Surgenor, et al (2017) which stated that video-based learning media can attract students' attention to learn and create student pleasure in the learning process. Research by Meij \& Meij (2014) that video can maximize learning by operating material of an application (software). Research by Panje, et al (2016) shown that video-based learning media is easy to use and duplicate.

Learning media already validated by material experts, media experts and students get a mean percentage of $91 \%$ with very valid criteria. Therefore, video-based learning media operating Microsoft Publisher 2010 can be used in the learning process. Based on the results of large group experiments when applying learning media in the experimental class, the use of learning media can improve student learning outcomes, the average students 'learning outcomes of the experimental class is higher than the average of control students' learning outcomes

The results are supported by Panje, et al (2013) which states that the video learning media can improve student learning outcomes. Research by Orus, et al (2016) also states that the use of video in learning has a positive impact on student learning outcomes. Research by Fajriah \& Churiyah (2016) that the experimental class learning outcomes are higher than the results of student learning control classes. Based on the result of t test data analysis, there is a significant difference between the average of experimental students' learning outcomes with the control class by the significance of 0.000 . So that can be said that video-based learning media operates Microsoft Publisher 2010 effective to use. According to Sarihan, et al (2016) that there are significant differences in student learning outcomes that use video in learning than students who do learning in a traditional way. 


\section{CONCLUSION \& SUGGESTION}

\section{Conclusion}

According with the purpose of research and development undertaken, it can be concluded that first, this research and development has resulted in video-based learning media office automation subjects on the subject operate Microsoft Publisher 2010. Second, based on the validation results of material experts, media experts and students, Video-based learning media running Microsoft Publisher 2010 indicates very feasible criteria . Third, based on the difference test result ( $t$ test) the average of learning result of experiment class student with control class, there is a significant difference on the average of second class learning result so that video-based learning media operates Microsoft Publisher 2010 is effective on learning process.

\section{Suggestion}

Researcher suggest that is better for teacher to use video-based learning media as learning media in activity. This is because the learning media can improve student learning outcomes. The use of instructional media as an impression in front of the classroom should use the help of LCD Projector devices and speakers. By using this instructional media, the teacher will be assisted in delivering the learning materials so capable to guide the students training. Therefore, before using this learning media, teachers are advised to explore the material presented in the module.

It is better too for students to use video-based learning media as a source of learning independently both in school and outside school. The use of instructional media as an independent learning resource for students should use computer devices and headphones. By using this learning media, students will be more independent and can improve students' understanding because students can see the operating procedures Microsoft Publisher 2010 clearly. Learning materials that exist in this media should be applied in student's daily basis. Utilization of the operation of Microsoft Publisher 2010 in making the product, can be used students in entrepreneurial activities.

Diffusion of video-based learning media, so that product can be used on a wider scale and can be done by uploading video on internet page.

\section{REFERENCES}

Aagaard, J. 2015. Drawn to distraction: A qualitative study of offtask use of educational technology. Computers \& Education, 87: 90-97

Akbar, S. 2013. Instrumen Perangkat Pembelajaran. Bandung: Remaja Rosdakarya

Arsyad, A. 2013. Media Pembelajaran Edisi Revisi. Jakarta: RajaGrafindo Persada 
Azlim, M. Amran, M. Rusli, M. R. 2015. Utilization of Educational Technology to Enhance Teaching Practices: Case Study of Community College in Malaysia. Procedia-Social and Behavioral Sciences, 195: 1793-1797

Dimyati \& Mudjiono. 2010. Belajar dan Pembelajaran. Jakarta: Rineka Cipta

Fajriah, U. N. \& Churiyah, M. 2016. Utilizing Instructional Media for Teaching Infrastructure Administration. Journal of Education and Practice, (Online), 7 (6): 100-111

Meij, H. Meij, J. 2014. A comparison of paper-based and video tutorials for software learning. Computers \& Education, 78: 150-159

Musfiqon, H.M. 2012. Pengembangan Media dan Sumber Pembelajaran. Jakarta: Prestasi Pustaka

Orus, C. Barles, M. J. Belanche, D. Casalo, L. Fraj, E. Gurrea, R. 2016. The effects of learnergenerated videos for Youtube on learning outcomes and satisfaction. Computers \& Education, 95: 254-269

Ospennikova, E. Ershov, M. \& Iljin, I. 2015. Educational Robotics as an Innovative Educational Technology. Procedia-Social and Behavioral Science, 214: 18-26

Panje, M., Sihkabuden. \& Toenlioe, A.J.E. 2016. Pengembangan Video Pembelajaran Bahasa Indonesia Teknik Membaca Puisi. Jurnal Pendidikan: Teori, Penelitian, dan Pengembangan, (Online), 1 (8): 1473-1478

Rante, P., Sudarto. \& Ihsan, N. 2013. Pengembangan Multimedia Pembelajaran Fisika Berbasis Audio-Video Eksperimen Listrik Dinamis di SMP. Jurnal Pendidikan IPA Indonesia, 2 (2): 203-208

Sadiman, A.S. 2012. Media Pendidikan Pengertian, Pengembangan dan Pemanfaatannya. Jakarta: RajaGrafindo Persada

Sarihan. A., Oray, N. C., Gullupinar, B., Yanturali, S., Atilla, R. \& Musal, Berna. 2016. The comparison of the efficiency of traditional lectures to video-supported lectures within the training of the Emergency Medicine residents. Tourkish Journal of Emergency Medicine, 16 (3): 107-111

Setyosari, P. 2013. Metode Penelitian Pendidikan dan Pengembangan. Jakarta: Kencana Prenadamedia Group

Smaldino, S.E., Lowther, D.L. \& Russel, J.D. 2011. Instructional Technology and Media For Learning: Teknologi Pembelajaran dan Media untuk Belajar. Terjemahan Arif Rahman. Jakarta: Kencana Prenadamedia Group

Sudjana, N. 2011. Penilaian Hasil Proses Belajar Mengajar. Bandung: Remaja Rosdakarya 
Sugiyono. 2015. Metode Penelitian Pendidikan (Pendekatan Kuantitatif, Kualitatif dan R\&D). Bandung: Alfabeta

Suprijono, A. 2010. Cooperative Learning Teori dan Aplikasi PAIKEM. Yogyakarta: Pustaka Belajar

Surgenor, D. Hollywood, L. Furey, S. Fiona, L. McGowan, L. Spence, M. Raats, M. McCloat, A.

Mooney, E. 2017. The impact of video technology on learning: A cooking skills experiment. Appetite, 114: 306-312 